\title{
PENERAPAN ISLAMIC MARKETING STRATEGY DAN ISLAMIC HUMAN RESOURCE MANAGEMENT DI UB. SURYA MADIUN
}

\author{
Nur Fauziah \\ Institut Agama Islam Negeri Ponorogo \\ Email: nurfauziah3628@gmail.com
}

\begin{abstract}
UB. Surya Madiun is a company engaged in the retail sector, namely minimarkets that provide basic daily needs. At UB. Surya Madiun in implementing the company's activities uses a sharia-based marketing strategy system and Islamic Human Resource Management to improve the quality of the company. This research was conducted to find out how the implementation of Islamic Marketing Strategy and Islamic Human Resource Management in UB. Surya Madison. In this analysis, qualitative data analysis method is used, namely by interviewing parties from UB. Surya Madison. In field research procedures that produce descriptive data, in the form of written or oral data from the people or observed behavior. Therefore, in this study, every symptom related to Islamic Marketing Strategy and Islamic Human Resource Management in UB. Surya Madiun will be thoroughly researched and endeavored to give meaning to every phenomenon found.
\end{abstract}

Keyword: Islamic Marketing Strategy, Islamic Human Resource Management, UB. Surya Madiun.

Abstrak: UB. Surya Madiun adalah sebuah perusahaan yang bergerak di bidang peretailan, yaitu minimarket yang menyediakan kebutuhan pokok sehari-hari. Di UB. Surya Madiun dalam pelaksanaan kegiatan perusahaan menggunakan sistem strategi pemasaran berbasis syariah serta Manajemen Sumber Daya Manusia yang Islami guna peningkatan kualitas perusahaan. Penelitian ini dilakukan guna mengetahui bagaimana penerapan Islamic Marketing Strategy dan Islamic Human Resource Management di UB. Surya Madiun. Dalam analisis ini menggunakan metode analisis data kualitatif, yaitu dengan cara mewawancarai pihak dari UB. Surya Madiun. Dalam prosedur penelitian lapangan yang menghasilkan data deskriptif, berupa data tertulis atau lisan dari orang-orang atau perilaku yang diamati. Oleh karena itu dalam penelitian ini dari setiap gejala yang terkait dengan Islamic Marketing Strategy dan Islamic Human Resource Management di UB. Surya Madiun akan diteliti secara menyeluruh serta diupayakan untuk memberikan makna dalam setiap fenomena yang ditemukan.

Kata Kunci: Islamic Marketing Strategy, Islamic Human Resource Management, UB. Surya Madiun. 
Niqosiya: Journal of Economics and Business Research

Vol. 1 No. 1, Januari-Juni 2021: 48-65

\section{PENDAHULUAN}

Sejalan dengan perkembangan teknologi serta ilmu pengetahuan yang begitu pesat akan membuat dampak kehidupan di masyarakat, baik dampak positif maupun negatif. Salah satunya yaitu perkembangan minimarket saat ini sedang mengalami peningkatan persaingan antar perusahaan retail tersebut.

UB. Surya Madiun bermula dari sebuah pemikiran guna mempermudah dan menyediakan kebutuhan pokok sehari-hari bagi warga Muhammadiyah khususnya dan masyarakat pada umumnya dan juga menindaklanjuti hasil Muktamar Muhammadiyah ke 47 di Makassar pada tahun 2015. Kemudian juga hasil kesepakatan rapat Pimpinan Daerah Muhammadiyah Kabupaten Madiun dan Majelis Ekonomi pada tanggal 17 Maret 2018 untuk segera mendirikan Amal Usaha Muhammadiyyah di bidang ekonomi. Maka terbentuklah panitia pendirian Amal Usaha Muhammadiyah yang bertugas untuk mempersiapkan berdirinya usaha tersebut.

\begin{tabular}{|c|c|}
\hline \multicolumn{2}{|c|}{$\begin{array}{l}\text { BADAN USAHA MILIK MUHAMMADIYAH } \\
\text { MAJELIS EKONOMI PIMPINAN DAERAH MUHAMMADIYAH } \\
\text { KABUPATEN MADIUN } \\
\text { “UB SURYA MADIUN" } \\
\text { EMAIL: suryamadiun01@ gmail.com }\end{array}$} \\
\hline Akta Notaris No. & 359 tanggal 25 Januari 2019 \\
\hline NPWP & $92.029 .501 .1-621.000$ \\
\hline Resmi Berdiri & 10 Februari $2019 \mathrm{M}$ atau 5 Jumadil Tsani $1440 \mathrm{H}$ \\
\hline
\end{tabular}

Kemudian pada tanggal 25 Januari 2019 dibuatlah Akta Notaris dengan Nomor 359 oleh Muhammad Ali Fauzi, SH. M. Kn didirikanlah Usaha Bersama Surya Madiun yang bergerak dibidang peritelan yaitu minimarket yang menyediakan kebutuhan pokok sehari-hari. Pada tanggal 10 Februari 2019 maka di launching Toko Surya Madiun 1 dan 2 yang masing-masing beralamat di:

a. Jalan Raya Pagotan-Dagangan Kecamatan Dagangan Kabupaten Madiun (Toko Surya Madiun 1).

b. Jalan Diponegoro Desa Uteran Nglandung Kecamatan Geger Kabupaten Madiun (Toko Surya Madiun 2). 
Usaha Bersama (UB) Surya Madiun mempunyai Visi "Menjadi badan usaha yang Islami, Ramah, Murah dan Aman” dengan Misinya adalah

a. Menciptakan dan menumbuh kembangkan kegiatan usaha yang luas agar dapat meraih keuntungan melalui penambahan cabang dan kerjasama.

b. Mengembangkan potensi sumber daya manusia, potensi pasar dan sistem pengelolaan perusahaan berdasarkan prinsip bisnis yang halal, sehat dan unggul.

c. Tata kelola yang baik dan berdasarkan standar mutu untuk memberikan kepuasan bagi pelanggan.

Direktur UB. Surya Madiun mengungkapkan bahwa banyaknya perusahaan retail disekitarnya yang saat ini sedang berkembang bukanlah saingan. Walaupun disekitar UB. Surya Madiun berdiri lebih dahulu beberapa Minimarket dan saling berdekatan. Dengan diterimanya perusahaan retail di masyarakat, bisnis tersebut mampu memberikan daya tarik kepada para investor untuk menanamkan modal pada bisnis tersebut. Untuk dapat mempertahankan eksistensi atau menarik konsumen secara maksimal, sebuah perusahaan retail harus mampu memberikan kepuasan kepada konsumen lewat strategi pemasaran yang diterapkan oleh masing-masing perusahaan retail tersebut. Kepuasan konsumen dapat tercapai apabila kebutuhannya dapat terpenuhi dan mendapatkan pelayanan terbaik. Akan tetapi kadang terdapat kendala bagaimana titik temu antara barang-barang yang dijual dengan pelayanan yang ditawarkan oleh perusahaan riteal tersebut.

Menyusun strategi yang tepat adalah hal terpenting bagi perusahaan karena untuk mengikat para konsumen untuk melakukan pembelian. Berbagai atribut yang melekat pada perusahaan adalah potensi yang perlu diperhatikan dan menyusun strategi yang baik dalam menjaring konsumen. Kemampuan para produsen atau pengusaha dalam melakukan strategi pemasaran yang tepat guna menghadapi keadaan pasar yang saat ini sangat kompleks, baik kemampuan dalam memasarkan produk dipasaran maupun kemampuan dalam bersaing dan bertahan dalam suatu persaingan usaha. Pemasaran (marketing) dapat dijadikan proses perusahaan dalam menciptakan nilai bagi pelanggan dan menjalin hubungan yang kuat dengan pelanggan, yang bertujuan menangkap nilai dari pelanggan sebagai imbalannya (Mubarok \& Maldina, 2007). Penerapan sistem syariah dalam dunia perdagangan sekarang ini mengalami perkembangan pesat. Banyak persaingan dagang yang menyebabkan perusahaan sulit untuk meningkatkan jumlah pelanggan. Sehingga perlu diadakan sebuah pemasaran 
yang dapat meningkatkan minat beli pelanggan dan membawa kemaslahatan bagi konsumen maupun perusahaan. Mengingat masyarakat Indonesia mayoritas muslim, sehingga perlu diadakan sebuah layanan dalam marketing yang menggunakan prinsip syariah. Dengan adanya sistem syariah konsumen merasa puas dengan pelayanan serta sistem yang diterapkan oleh sebuah perusahaan. Dalam Islam pemasaran (marketing) memang dibenarkan, apabila saat proses transaksinya terhindar dari hal-hal yang dilarang dalam Islam (Farida, 2011).

Unsur terpenting dalam kemajuan sebuah perusahaan adalah Sumber Daya Manusia (SDM). Sumber Daya Manusia (SDM) memiliki peranan yang sangat penting dalam perusahaan. Dengan Manjemen Sumber Daya Manusia dapat memposisikan karyawan sebagai partner dalam menjalankan segala aktivitas di perusahaan untuk memimpin dari setiap tingkatan organisasi di perusahaan. Jika perusahaan menginginkan karyawan mempunyai karakter kepemimpinan serta keterampilan manajerial yang baik, sehingga diperlukan pelatihan dan pengembangan diri untuk karyawan guna meningkatkan kualitas kerjanya. Setiap perusahaan harus memiliki Sumber Daya Manusia yang baik karena merupakan asset yang paling berharga. Sebuah perusahaan mengalami pencapaian dikarenakan adanya dukungan dari peran direksi dan manajer yang terlibat dalam pengelolaan Sumber Daya Manusia dan para staf yang bekerja dengan sebaik-baiknya (Makruflis, 2019). UB. Surya Madiun merupakan salah satu perusahaan yang menerapkan Islamic Human Resource Management dalam kinerja perusahaan. Perusahaan melakukan segala aktivitas disesuaikan prinsip syariah, karena tidak hanya untuk menguntungkan didunia akan tetapi juga diakhirat.

\section{TINJAUAN LITERATUR}

\section{Islamic Marketing Strategy (Strategi Pemasaran Islam)}

Secara etimologis, strategi berasal dari bahasa Yunani yaitu strategos atau Jendral. Awal mulanya strategi yaitu dari peristiwa peperangan atau sebagai sesuatu untuk mengalahkan lawan. Kemudian strategi tersebut dikembangkan untuk kegiatan organisasi yang termasuk dalam keperluan ekonomi, sosial, budaya dan agama (Ratnasari, 2019).

Dalam ilmu manajemen, strategi merupakan rencana yang tepat untuk mencapai sasaran tertentu dalam sebuah kegiatan dan saling berhubungan antara waktu dan ukuran. Dalam sebuah perusahaan, strategi dapat dikatakan sebagai faktor terpenting 
agar perusahaan mampu menjalankan aktivitasnya dengan baik. Strategi menggambarkan bagaimana arah usaha yang dijalankan mengarah pada lingkungan yang dipilih dan merupakan sebuah pedoman dalam mengalokasikan sumber daya usaha suatu organisasi (Ratnasari, 2019).

Dalam Kamus Besar Bahasa Indonesia strategi merupakan rencana yang cermat mengenai suatu kegiatan untuk mencapai sasaran khusus (Ratnasari, 2019). Dalam sebuah persaingan produk keberadaan strategi sangatlah penting baik dalam pasar sasaran, posisi pasar serta segmentasi yang dilakukan tidak berjalan jika tidak diikuti strategi yang tepat. Jadi strategi merupakan langkah-langkah yang harus dijalankan oleh perusahaan dalam mencapai suatu tujuan. Strategi adalah penentuan sebuah tujuan jangka panjang dari suatu organisasi dan dijadikan sebagai alternatif dalam melakukan tindakan serta alokasi sumber daya yang dibutuhkan dalam mencapai tujuan tersebut.

Definisi Pemasaran menurut Asosiasi Pemasaran Amerika bahwa pemasaran adalah satu fungsi dari organisasi dan seperangkat proses untuk menciptakan, mengkomunikasikan dan menyerahkan nilai kepada pelanggan serta mengelola hubungan pelanggan dengan cara yang menguntungkan organisasi dan pemilik sahamnya. Menurut Gunara dan Sudibiyo pemasaran adalah sebuah konsep yang muncul untuk menghasilkan sebuah penjualan sehingga dapat memberikan keuntungan bagi perusahaan atau individu (Ramadhani, 2018).

Pemasaran dalam literatur fiqh islam disebutkan wakalah atau perwakilan yang artinya penyerahan dari seseorang yang dapat dilakukan oleh individu maupun dapat diwakilkan kepada orang lain. Islamic Marketing adalah suatu disiplin dalam bisnis strategis yang mengarahkan proses penciptaan, penawaran dan perubahan value dari inisiator kepada stakeholder nya yang dalam keseluruhannya merupakan sebuah proses yang disesuaikan dengan akad serta ketentuan-ketentuan muamalah dalam islam (Ramadhani, 2018). Rasulullah SAW telah mengajarkan tentang bagaimana cara pemasaran yang tidak lepas dari aturan dan norma, yaitu dengan memegang teguh kebenaran, amanah, kejujuran, namun tetap mendapatkan keuntungan. Dan nilai tersebut sebagai landasan dalam menjalankan usaha, dengan sikap islamiah tersebut sangat direkomendasikan oleh banyak ayat-ayat dalam Al-Qur'an.

Jadi Islamic Marketing Strategy atau Strategi pemasaran islam adalah langkahlangkah yang harus dijalankan perusahaan yang berupa proses penciptaan, proses 
Niqosiya: Journal of Economics and Business Research

Vol. 1 No. 1, Januari-Juni 2021: 48-65

penawaran ataupun perubahan nilai, yang dilakukan tidak boleh bertentangan dengan akad serta prinsip-prinsip muamalah dalam islam.

Jika suatu perusahaan menginginkan usahanya berbasis syariah, maka budaya perusahaan haruslah berdasarkan nilai-nilai islami. Dalam pengimplementasian juga harus berdasarkan prinsip syariah. Kepribadian Institusi dibentuk oleh peranan penting dari Values atau nilai-nilai islami.

\section{Prinsip Islamic Marketing}

Terdapat 17 prinsip dari Islamic Marketing sebagai berikut:

a. Information Technology allows us to be transparent (change)

Dalam sebuah perubahan diperlukan sikap yang cermat dalam menghadapi, karena perubahan dapat terjadi kapan saja. Kekuatan perubahan meliputi unsur perubahan-perubahan yaitu teknologi, sosial-kultural, politik-legal, ekonomi dan perubahan pasar.

b. Be Respectful to Your Competitors (Competitor)

Persaingan usaha terjadi serba dinamis, maka dalam menerapkan Islamic Marketing perusahaan harus menggunakan cara yag tepat. Adanya globalisasi dan perubahan teknologi menyebabkan adanya suatu persaingan usaha. Dalam menghadapi suatu persaingan yang sangat kompleks maka dibutuhkan kebesaran jiwa dalam menerima persaingan dengan hati yang tulus dan terbuka, dikarenakan masyarakat luas sebagai konsumen memiliki peran sebagai pemegang segala kendali pasar. Perusahaan akan dipandang positif apabila kompetisinya dilakukan dengan adil dan jujur.

c. The Emergence of Customers Global Paradox (Customer)

Perubahan perilaku dan cara pandang masyarakat merupakan salah satu bentuk munculnya revolusi dibidang teknologi informasi dan telekomunikasi. Saat ini pelanggan tidak hanya untuk membeli apa yang dibutuhkan tetapi juga mempunyai keinginan serta harapan atas produk atau jasa yang dibelinya. Hal ini terjadi karena semakin maraknya akses informasi dan pilihan produk yang bervariasi, sehingga para konsumen mempunyai keinginan yang semakin spesifik dan harapan yang tinggi.

d. Develop a Spiritual-Based Organization (Company) 
Diera globalisasi dan ditengah ketatnya persaingan usaha, perusahaan haruslah merencanakan serta merenungkan kembali prinsip-prinsip dasar perusahaannya.

\section{e. View Market Universally (Segmentation)}

Segmentasi merupakan sebuah seni memanfaatkan dan mengidentifikasi bagaiman peluang di pasar. Segmentasi dapat dijadikan sebuah pengetahuan dalam melihat pasar didasarkan pada variabel-variabel yang berkembang di masyarakat. Perusahaan haruslah kreatif dan inovatif dalam menyikapi segala perkembangan yang terjadi didalam melihat situasi pasar. Dikarenakan segmentasi adalah langkah awal dalam penetuan seluruh aktivitas perusahaan.

\section{f. Target Customer's Hearth and Soul (Targeting)}

Setelah melakukan pemetakan dan pembagian pasar dalam beberapa segmen, kemudian menentukan target pasar yang akan dituju. Targeting merupakan sebuah strategi dalam mengalokasikan sumber daya perusahaan dengan efektif, dikarenakan adanya keterbatasan sumber daya yang dimiliki.

\section{g. Build a Belief System (Positioning)}

Kemudian langkah yang selanjutnya dilakukan ialah bagaimana membentuk positioning yaitu strategi memperebutkan posisi kepada konsumen, sehingga strategi ini berkaitan dengan kompetensi untuk pelanggan, keyakinan, serta kepercayaan.

h. Differ Yourself with a Good Package of Content and Context (Differentiation)

Diferensiasi diartikan suatu tindakan untuk merancang beberapa perbedaan yang memiliki makna dalam tawaran perusahaan. Akan tetapi, penawaran ini tidak hanya janji-janji saja, melainkan didukung dengan kenyataan yang sesuai.

i. Be Honest with Your 4 Ps (Marketing Mix)

Dalam hal ini perusahaan harus menyatukan tawaran dengan akses yang telah tersedia atau yang dimaksud dengan Marketing Mix. Penyatuan menjadi kunci dalam keberhasilan usaha pemasaran dari sebuah perusahaan.

\section{j. $\quad$ Practice Realitionship-Based Selling (Selling)}

Dalam hal ini Selling diartikan tidak hanya sebagi aktivitas menjual produk ke konsumen saja. Dalam arti sederhana penjualan merupakan penyerahan barang maupun jasa dari penjual ke konsumen sesuai harga hasil kesepakatan yang dilakukan secara sukarela. Penjualan secara universal merupakan kegiatan untuk 
memaksimalkan kegiatan penjualan untuk menghasilkan situasi Win-Win solution antar penjual dan pembeli.

k. Use a Spiritual Brand Character (Brand)

Merk atau brand merupakan ciri khas yang dimiliki sebuah produk atau jasa dari sebuah perusahaan. Brand melambangkan sebuah value (nilai) yang diberikan perusahaan kepada para pelanggan. Menurut pandangan islamic marketing, brand merupakan nama baik yang menjadi kekhasan dari seseorang atau perusahaan. Memang dalam membentuk brand yang kuat adalah hal terpenting, akan tetapi harus tetap sesuai prinsip syariah.

1. Service Should Have the Ability to Transform (Service)

Seorang pelaku usaha yang menginginkan perusahaannnya besar yang berbasis islamic marketing haruslah memperhatikan service yang ditawarkan untuk mempertahankan kepuasan konsumen.

m. Practice a Reliable Business Process (Process)

Tingkat Quality, Cost dan Delivery atau QCD mencerminkan sebuah proses. Kualitas dari sebuah produk akan tercermin bagaimana proses yang dijalankan, dari proses produksi sampai delivery ke konsumen yang dilakukan dengan tepat waktu dan biaya yang efektif dan efisien. Dalam konteks Cost proses merupakan bagaimana sebuah proses dilakukan dengan mengeluarkan biaya seminimal mungkin, tetapi kualitas tetap terjamin. Dalam konteks delivery proses merupakan bagaimana proses dalam menyampaikan produk yang ditawarkan perusahaan kepada konsumen. Proses Delivery merupakan proses terpenting dikarenakan berhubungan langsung dengan konsumen, apakah konsumen puas terhadap layanan perusahaan.

n. Create a Balanced Value to Your Stakeholders (Scored)

Dalam Islamic Marketing prinsipnya yaitu menciptakan value bagi para Stakeholders-nya yang nantinya mengarah pada tujuan perusahaan dijalankan. Dalam menjalankan usaha ada sebuah peranan penting Stakeholders utama yaitu People, Customer dan Stakeholders.

o. Create a Noble Cause (Inspiration)

Layaknya manusia, suatu perusahaan haruslah mempunyai impian (Dream), yaitu impian yang akan dicapai yang akan mengarahkan manusia dan perusahaan dalam sepanjang perjalanan usaha. 


\section{p. Develop an Ethical Corporate Culture (Culture)}

Sebuah perusahaan yang menggunakan prinsip syariah, pastinya budaya perusahaan berbeda dengan budaya yang berkembang di konvensional. Seluruh sikap, perilaku serta peraturan di perusahaan harus mampu mencerminkan nilainilai syariah. Budaya-budaya perusahaan yang menerapkan prinsip syariah:

1) Budaya mengucapkan salam

Hal termudah yang dapat dilakukan ialah mengucapkan salam dengan senyuman.

2) Ramah, murah hati dan memberi pelayanan dengan sopan

Dalam menjalankan hubungan dengan para pelanggan haruslah bersikap ramah, murah hati dan sopan.

3) Cara berpakaian

Perusahaan yang berbasis syariah pada dasarnya pakaian karyawan haruslah sesuai syariah, karena hal ini yang membedakan antara perusahaan islam dan non syariah. Pakaian yang rapi sesuai syariah, maka akan menjadi cerminan bagi diri setiap karyawan dan dapat memperkuat jati diri dari perusahaan.

4) Lingkungan kerja yang bersih

Lingkungan kerja yang bersih merupakan cerminan perusahaan yang bernilai islami. Dikarenakan lingkungan yang bersih merupakan cerminan kebersihan hati orang-orang yang ada dilingkungan tersebut.

q. Measurement Must be Clear and Transparent (Institution)

Organisasi dijadikan sebagai kendaraan dalam menjalankan visi dan misi yang sudah ditetapkan harus terstruktur dengan baik serta targetnya jelas untuk masing-masing Milestone dari sasaran yang telah ditentukan sebelumnya (Farida, 2011, hlm. 41-48).

\section{Tujuan Islamic Marketing}

a. Memberikan segala kemudahan kepada para konsumen dengan cara memaksimalkan kualitas.

b. Menyediakan berbagai pilihan jenis produk sehingga para konsumen mempunyai beragam pilihan (diversifikasi produk).

c. Memudahkan para konsumen untuk membeli secara berulang-ulang produk yang ditawarkan. 
Niqosiya: Journal of Economics and Business Research

Vol. 1 No. 1, Januari-Juni 2021: 48-65

d. Memaksimalkan kepuasan para konsumen (Ratnasari, 2019).

\section{Karakteristik Islamic Marketing}

Manurut Kertajaya, karakteristik Islamic Marketing terdiri dari unsur-unsur dibawah ini:

a. Ketuhanan (Rabbaniyyah)

Dalam pemasaran syariah terdapat ciri khas yang tidak dimiliki oleh pemasaran konvensional yaitu sifatnya religious (Diniyyah). Seorang Islamic Marketer harus meyakini bahwa hukum-hukum syariah merupakan hukum yang paling adil, paling selaras dalam kebaikan, dapat mencegah kerusakan, mewujudkan kebenaran, menebarkan kemaslahatan serta memusnahkan keburukan.

b. Etis (Akhlaqiyyah)

Pemasaran syariah adalah suatu konsep pemasaran dimana sangat mengedepankan nilai moral dan etika, tidak memandang agama apapun. Dikarenakan nilai-nilai moral dan etika merupakan nilai universal yang diajarkan oleh semua agama.

c. Realistis (Al-Waqiyyah)

Al-Waqiyyah atau realistis adalah menjalankan suatu bisnis tanpa adanya kebohongan dalam menjalankan transaksi dan harus sesuai realita tanpa membedakan suku, ras, agama.

d. Humanistis (Al-Insaniyyah)

Humanitis (Al-Insaniyyah) adalah bahwa syariah tercipta untuk mengangkat derajat manusia, dengan panduan syariah maka sifat kemanusiaannya akan terjaga dan terpelihara. Dengan adanya nilai humanitas perilaku manusia akan terkontrol serta seimbang, sehingga manusia tidak akan serakah, yang dalam meraih keuntungan mereka cenderung menghalalkan berbagai cara.

\section{Islamic Human Resource Management (Manajemen Sumber Daya Manusia Islami)}

Dalam bahasa Inggris manajemen berasal dari Management yang berarti mengatur atau mengelola. Secara umum manajemen merupakan upaya dalam mengatur sumber daya yang dimiliki guna mencapai tujuan organisasi yang telah ditentukan.

Sumber Daya diartikan sebagai alat untuk mencapai sebuah tujuan atau kemampuan untuk mendapatkan laba dari sebuah kesempatan-kesempatan yang ada. 
Sumber Daya Manusia dapat diartikan sebagai individu yang merancang dan memproduksi keluaran untuk pencapaian strategis dan tujuan yang telah ditentukan oleh organisasi (Yusuf, 2015).

Manajemen Sumber Daya Manusia merupakan sebuah penataan bagi pegawai yang didalamnya meliputi tata cara dalam memperoleh serta menggunakan tenaga kerja secara efisien untuk mencapai tujuan yang telah ditentukan. Manajemen Sumber Daya Manusia Islami diarahkan pada dua perbuatan manusia didunia, yaitu perbuatan yang disebut dengan muamalah dan perbuatan yang dikategorikan ibadah. Pada dasarnya suatu perbuatan ibadah dilakukan sesuai dengan dalil atau ketentuan yang terdapat dalam Al-Qur'an dan Hadits yang menyatakan bahwa perbuatan tersebut harus atau boleh dilakukan. Sedangkan dalam Muamalah pada dasarnya semua perbuatan boleh dilakukan kecuali ada ketentuan dalam Al-Qur'an dan Hadits yang melarangnya (Samsuni).

\section{Tujuan Manajemen Sumber Daya Manusia}

Tujuan utama Manajemen Sumber Daya Manusia menurut Soekidjo Notoatmojo yaitu untuk meningkatkan kontribusi dari Sumber Daya Manusia terhadap organisasi untuk mencapai produktivitas dari organisasi tersebut. Bahwa semua kegiatan organisasi dalam menggapai suatu tujuan ditentukan oleh kinerja dari Sumber Daya Manusianya, oleh karenanya harus dikelola dengan baik agar berdaya guna dan dapat berhasil dalam mencapai tujuan organisasi (Dacholfany, 2017). Jadi tujuan utama Manajemen Sumber Daya Manusia ialah sebuah rencana yang terorganisir dalam usaha melaksanakan kegiatan yang terpantau dengan baik dan dengan cara melaksanakan evaluasi sehingga terjadi peningkatan yang baik dari setiap kegiatannya.

\section{Landasan dan Dasar Manajemen Sumber Daya Manusia Islami}

Dalam mengembangkan Sumber Daya Manusia, islam sangatlah memberikan perhatian serta pandangan yang sangat mendalam. Tidak hanya manusia didunia sebagai khalifah, akan tetapi juga termasuk pada nilai-nilai sikap dan perilaku manusia tersebut (Samsuni). Allah berfirman dalam QS. Al-Baqarah ayat 30:

"Dan (ingatlah) ketika Tuhanmu berfirman kepada para malaikat, "Aku hendak menjadikan khalifah dibumi". Mereka berkata, "Apakah Engkau hendak menjadikan orang yang merusak dan menumpahkan darah disana, sedangkan 
Niqosiya: Journal of Economics and Business Research

Vol. 1 No. 1, Januari-Juni 2021: 48-65

kami bertasbih memuji-Mu dan menyucikan nama-Mu?" Dia berfirman, "Sungguh, Aku mengetahui apa yang tidak kamu ketahui".

\section{METODE PENELITIAN}

Dalam penelitian ini menggunakan jenis penelitian yaitu studi pustaka dimana data diperoleh dari beberapa sumber. Penelitian ini bersifat deskriptif kualitatif atau menggambarkan suatu objek dalam penelitian. Sedangkan jenis data yang digunakan ialah data kualitatif yang bersumber dari data primer dan data sekunder. Data primer merupakan data yang didapatkan langsung dari lapangan. Sedangkan data sekunder merupakan sumber data yang diperoleh tidak secara langsung memberikan data kepada peneliti atau diambil dari data pendukung seperti buku, internet, jurnal, artikel, majalah dan sumber lainnya.

\section{HASIL DAN PEMBAHASAN}

\section{Penerapan Islamic Marketing Strategy di UB. Surya Madiun}

Didalam Islamic Marketing diajarkan bahwa pemasar haruslah jujur kepada konsumen maupun orang lain. Prinsip-prinsip dalam Islam dapat mencegah pemasar terjerumus pada Kelirumologi (Bujukan orang untuk berbelanja secara berlebihan atau pemasaran yang akhirnya menciptakan kemasan produk dengan sebaik-baiknya akan tetapi tidak dengan produknya), sehingga dibutuhkan nilai-nilai islami yang seharusnya dijunjung oleh seorang pemasar.

Hermawan dan Muhammad syakir menawarkan konsep pemasaran syariah diantaranya:

a. Syariah Marketing Strategy, digunakan untuk memenangkan mind-share yang dapat dilakukan dengan cara memetakan pasar berdasarkan pertumbuhan pasar, keunggulan kompetitif serta situasi para pesaing.

b. Syariah Marketing Tactic, digunakan untuk memenangkan market-share dengan cara menerapkan diferensiasi yang kreatif dan inovatif dengan melakukan marketing mix.

c. Syariah Marketing Value, digunakan untuk memenangkan heart-share (kecintaan para pelanggan terhadap produk yang ditawarkan).

d. Syariah Marketing Scorecard, digunakan untuk menghasilkan keseimbangan value kepada para stakeholders. 
e. Syariah Marketing Enterprise, digunakan untuk menciptakan sebuah inspirasi (inspiration) (Kertajaya \& Sula).

Terdapat empat hal yang menjadi Key Succes Factors (KSF) dalam mengelola Islamic Marketing Strategy, yaitu:

a. Shiddiq (benar dan jujur), bagi pengusaha haruslah memiliki perilaku yang benar dan jujur sepanjang melakukan kegiatan perusahaan, baik dalam menjalin hubungan dengan pelanggan, dalam bertransaksi dengan konsumen, dan dalam kegiatan yang berupa perjanjian dengan mitra bisnisnya.

b. Amanah (terpercaya) maksudnya keinginan dalam memenuhi sesuatu yang disesuaikan dengan ketentuan. Amanah merupakan sebuah nilai yang berkaitan dengan nilai kejujuran.

c. Fathanah (cerdas), maksudnya seorang pemimpin yang Fathanah merupakan pemimpin yang mengerti, mengetahui serta menghayati secara keseluruhan dalam segala hal yang menjadi tugas dan kewajibannya.

d. Tabligh (komunikatif), maksudnya dalam berbisnis seseorang seharusnya mampu mengomunikasikan visi dan misinya dengan baik kepada para karyawan dan stakeholders (Kertajaya \& Sula).

UB. Surya Madiun merupakan salah satu perusahaan retail yang telah menerapkan berbagai strategi pemasaran yang disesuaikan dengan prinsip syariah, diantaranya:

a. Pengelolaan disiplin, jujur dan amanah.

b. Menggunakan Prinsip IRMA

1) Islami (segala aktivitasnya disesuaikan dengan nilai-nilai islam).

2) Ramah (tidak membedakan pembeli dan pemasok barang).

3) Murah (selisih sedikit tetapi konsumen puas).

4) Aman (aman bagi konsumen, aman bagi pemodal, aman dunia dan akhirat, aman barangnya).

c. Strategi Internal (menggunakan 5S) atau investasi akhirat:

1) Senyum

Senyum merupakan sebuah bentuk ibadah yang berpahala yang dilakukan dengan mudah dan dianjurkan dalam islam.

2) Salam 
Salam artinya damai atau keselamatan, maka dari itu islam mengajarkan untuk selalu mengucapkan salam kepada saudara muslim lainnya karena mengandung doa yang luar biasa.

3) Sapa

Sapa merupakan sebuah bentuk ibadah guna menjalin hubungan silaturahmi dengan sesama muslim.

4) Sopan

Sopan merupakan hormat dengan takzim menurut adat yang baik, sikap ini sangat dianjurkan dalam islam.

5) Santun dalam bicara

Santun merupakan sebuah sikap yang baik dan halus budi bahasa dan tingkah lakunya, belas kasihan dan suka menolong.

d. Strategi Eksternal:

1) Mengadakan Promosi lewat media sosial.

2) Tasaruf (Pengelolaan)

a) Terkait pengelolaan zakat sebesar 2,5\% diberikan kepada asnaf.

b) Kerjasama dengan Lazismu.

c) Seragam Karyawan.

d) Kerjasama dengan kegiatan dan birokrasi Muhammadiyah.

e) Program Milad Muhammadiyah.

f) Seluruh Pendakwah memperkuat kegiatan ekonomi.

\section{Penerapan Islamic Human Resource Management di UB. Surya Madiun}

Ruang lingkup Manajemen Sumber Daya Manusia yang berbasis nilai-nilai syariah diantaranya (Samsuni, hlm. 44-49):

a. Rekrutmen

Dalam Islam, proses rekrutmen dianjurkan untuk menentukan atau menyeleksi para karyawan yang nantinya diterima oleh perusahaan maupun organisasi yang seharusnya pelamar haruslah kompeten serta religius (persyaratannya haruslah beragama Islam dan berhijab). Di UB. Surya Madiun untuk memperoleh karyawan menggunakan sistem recruitmen, pastinya recruitmen yang dilakukan guna menyaring para pelamar kerja yang sesuai dengan tujuan 
perusahaan. UB. Surya Madiun memberikan kesempatan kepada masyarakat sekitar untuk bergabung menjadi bagian dari UB. Surya Madiun.

b. Seleksi

Seorang Manajer muslim haruslah mengetahui ketentuam didalam Al-Qur'an yang dapat menghindari perekrutan yang tidak jelas serta tindakan yang tidak profesional dari nepotisme guna mencegah deskriminasi di lokasi kerja. Ciri-ciri profesionalisme dalam pandangan Islam ada tiga hal yaitu:

1) Ahliyah (Keahlian)

Dalam Islam orang yang menduduki sebuah jabatan haruslah memiliki keahlian serta kecakapan dalam tugasnya. Karena islam mengingatkan jika mengangkat orang yang tidak sesuai, dianggap menyalahi amanah dan berkhianat kepada Allah SWT, Rasul-Nya dan berkhianat terhadap kaum muslim.

2) Himmatul 'Amal (Etos Kerja Tinggi)

Islam sangatlah mendorong kepada kaum muslim untuk bekerja keras, bersungguh-sungguh dalam mengeluarkan tenaganya serta kemampuannya dalam bekerja, disamping dorongan untuk beribadah tetapi juga adanya keinginan untuk mendapat imbalan atau penghargaan baik material maupun non material.

3) Amanah (Terpercaya dan Bertanggungjawab)

Islam menganjurkan kepada seorang pekerja muslim haruslah amanah yaitu kemampuan untuk menjalankan tugas dan mampu bertanggungjawab atas tugas yang telah diamanahkan, islam menilai salah satu jenis ibadah yang utama yakni memenuhi amanah kerja.

UB. Surya Madiun dalam melakukan penerimaan karyawan disamping melakukan rekrutmen, mereka juga menggunakan proses seleksi. Dikarenakan banyaknya pelamar yang menginginkan untuk bergabung dengan UB. Surya Madiun. Proses seleksi dilakukan guna menentukan jabatan yang akan ditempati bagi para pelamar yang disesuaikan dengan kemampuan yang dimiliki.

c. Kontrak Kerja

Didalam kontrak kerja, Islam menggolongkan sebagai suatu perjanjian sewamenyewa (Al-Ijarah), yaitu Ijarah A'yun, sewa-menyewa tenaga manusia untuk melaksanakan suatu pekerjaan. Dalam melakukan kontrak dengan seorang pekerja 
haruslah menentukan jenis pekerjaannya sekaligus durasi bekerja, gaji dan tenaga yang dikeluarkan.

UB. Surya Madiun telah memiliki sebanyak 22 karyawan dengan berbagai job deskripsi yang berbeda, diantaranya:
1) Pemegang Saham
2) Dewan Komisaris
3) Direktur
4) Manager
5) Staff Administrasi
6) Marketing
7) Kasir dan Pramuniaga
8) Security (Keamanan)

\section{STRUKTUR ORGANISASI}

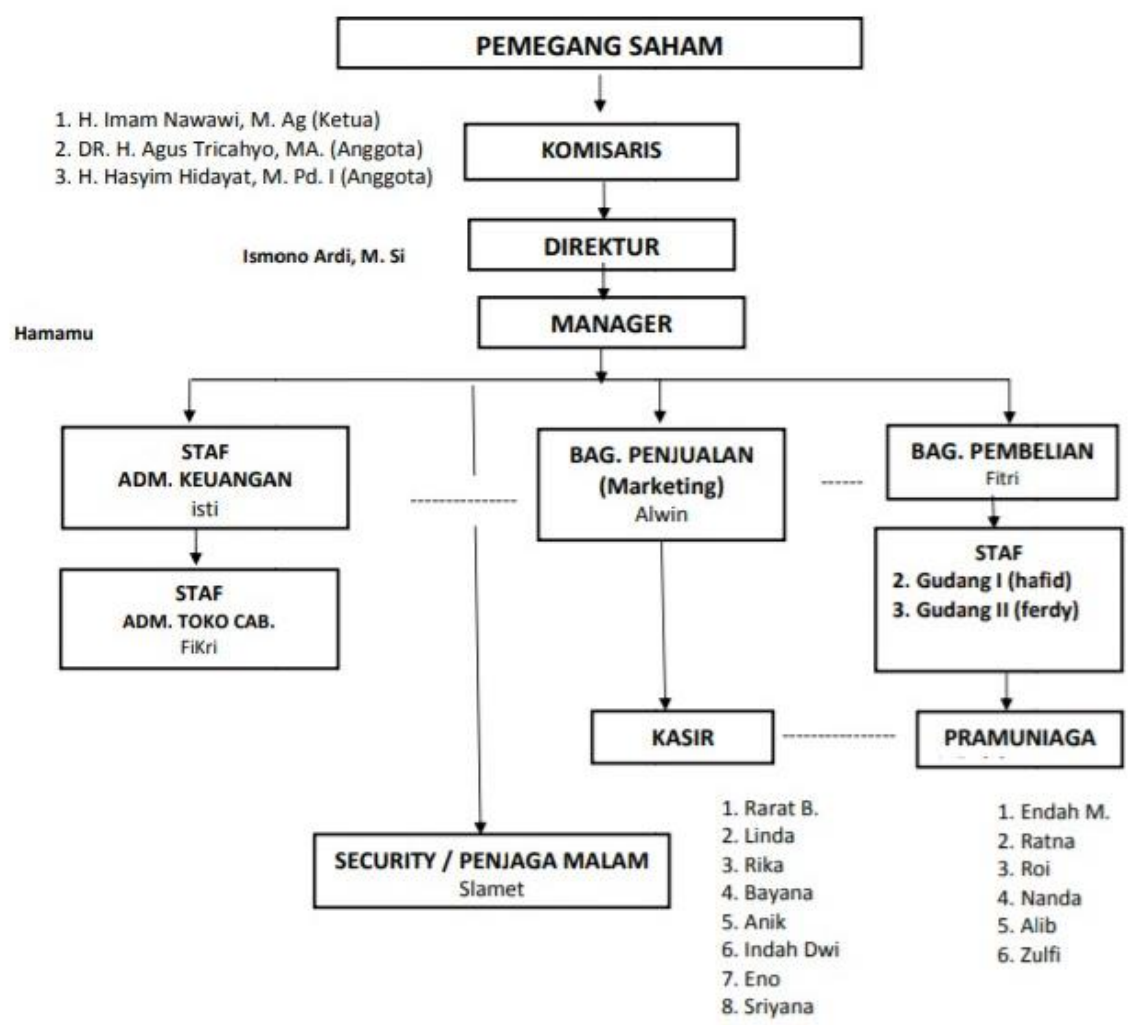

Gambar 1 Struktur Organisasi di UB. Surya Madiun

Dengan adanya masing-masing tupoksi kerja diharapkan mampu memberikan rasa tanggung jawab terhadap pekerjaan yang dijalankan. UB. Surya Madiun menerapkan peraturan bagi karyawan yang mendapat shift kerja pagi wajib 
mengikuti kegiatan mengaji bersama dan ketika hari jum'at ketika jam 11.30 WIB toko sementara ditutup dan para karyawan putra melaksanakan sholat jumat serta kembali dibuka jam 13.00 WIB. Dengan adanya kegiatan tersebut, disamping untuk bermuamalah tetapi juga meningkatkan ketaqwaan kepada Allah SWT. Waktu bekerja kepada masing-masing karyawan adalah tujuh jam yaitu shift pagi (07.0014.00 WIB) dan shift siang (14.00-21.00 WIB).

d. Penilaian Kerja

Seorang Manajer Muslim haruslah peduli terhadap penilaian yang disesuaikan dengan syariah yang menjunjung tinggi transparansi serta tanggungjawab. Bertanggungjawab untuk memberikan penilaian kepada karyawan dengan adil. Penilaian kinerja haruslah dilakukan sesuai aturan di dalam Al-Qur'an.

UB. Surya Madiun telah menerapkan penilaian terhadap para karyawan, dimana penilaian tersebut dapat dijadikan acuan dalam proses kenaikan jabatan serta pemberian upah atau gaji. Penilaiannya meliputi kedisiplinan, kinerja karyawan serta kemampuan para karyawan dalam melayani konsumen.

e. Pelatihan dan Pengembangan

Islam menegaskan jika dalam pelatihan dan pengembangan haruslah mencakup segalanya, baik dalam pengembangan moral dan peningkatan spiritual manusia dan nantinya dimuat dalam kebijakan fiskal. Pelatihan dan pengembangan harusnya dapat meningkatkan keyakinan kepada Allah SWT dan untuk meningkatkan keterampilan serta pengetahuan pekerja sehingga dapat meningkatkan level mereka. Di UB. Surya Madiun sendiri telah melakukan pelatihan dan pengembangan kepada karyawan didalam melaksanakan aktivitas perusahaan.

f. Kompensasi

Islam telah menentukan upah bagi para pegawai disesuaikan pada kondisi, tanggungjawab dan jenis pekerjaannya. Semua itu adalah asas pemberian upah yang disesuaikan dengan Firman Allah SWT dalam Q.S. Al-Ahqaf/49:19. UB. Surya Madiun telah menetapkan besaran upah bagi para karyawan sesuai dengan posisi pekerjaan yang dijalankan oleh para pekerja. 
Niqosiya: Journal of Economics and Business Research

Vol. 1 No. 1, Januari-Juni 2021: 48-65

\section{KESIMPULAN}

Islamic Marketing Strategy atau Strategi pemasaran islam adalah langkahlangkah yang harus dijalankan perusahaan yang berupa proses penemuan, proses penawaran ataupun perubahan nilai, yang dilakukan tidak boleh bertolak belakang dengan akad serta prinsip-prinsip muamalah dalam islam. Manajemen Sumber Daya Manusia Islami ditujukan pada dua perbuatan manusia didunia, yakni perbuatan dalam bermuamalah dan perbuatan yang tergolong ibadah.

UB. Surya Madiun merupakan usaha yang bergerak dibidang peritelan yang menyediakan kebutuhan sehari-hari. UB. Surya Madiun berdiri dibawah naungan Muhammadiyah. UB. Surya Madiun dalam memasarkan produknya menggunakan Islamic Marketing. Dalam Islamic Human Resource Management UB. Surya Madiun telah menerapkan dengan segala aktivitasnya, seperti cara mendapatkan karyawan, pembagian pekerjaan dan waktu bekerja serta kompensasi.

\section{REFERENSI}

Dacholfany, M. I. (2017). Inisiasi Strategi Manajemen Lembaga Pendidikan Islam Dalam Meningkatkan Mutu Sumber Daya Manusia Islami di Indonesia Dalam Menghadapi Era Globalisasi. At-Taqdid Vol. 1 No. 1 Januari-Juni 2017.

Farida, I. (2011). Pengaruh Penerapan Layanan Marketing Syariah dan Kepuasan Pelanggan Terhadap Loyalitas Pelanggan (Rumah Makan Wong Solo Cabang Tebet). Skripsi. Jakarta: UIN Syarif Hidayatullah.

Kertajaya, H. \& Sula, M. S. (2006). Syariah Marketing. Bandung: Mizan Pustaka.

Makruflis, M. (2019). Dampak Positif Sumber Daya Manusia Islami Bagi SDM di Bank Syariah Mandiri KCP Ujung Tanjung Rohil. Jurnal Nathiqiyah Vol. 2 No. 1 JanJun 2019.

Mubarok, N. \& Maldina, E. Y. (2017). Strategi Pemasaran Islami Dalam Meningkatkan Penjualan Pada Butik Calista. Jurnal I-Economic Vol.3 No. 1 Juni 2007.

Ramadhan, A. D. I. (2018). Implementasi Marketing Mix Berbasis Syariah Pada PT BRI Syariah Kcp Kepanjen. SKRIPSI. Malang: Jurusan Perbankan Syariah UIN Malang.

Ratnasari, A. (2019). Strategi Pemasaran di BMT Surya Kencana Balong Ponorogo Dalam Perspektif Ekonomi Syariah. Skripsi, Ponorogo: Jurusan Hukum Ekonomi Syariah Fakultas Syariah.

Samsuni. (2020). Manajemen Sumber Daya Manusia Berbasis Nilai-nilai Islami. Tarbiyah Islamiyah: Jurnal Ilmiah Pendidikan Agama Islam, 10(1).

Yusuf, B. (2015). Manjemen Sumber Daya Manusia di Lembaga Keuangan Syariah. Jakarta: Rajawali Pers. 